\title{
Áhrif mismunandi hugtakanotkunar á viðhorf almennings
}

\author{
Viðar Halldórsson, prófessor í félagsfræđi, Háskóli Î́lands
}

\begin{abstract}
Útdráttur
Pólitískri orðræðu er stýrt með notkun tungumálsins. Stjórnmálamenn miðla skilaboðum, beint og óbeint, í gegnum tungumálið í peim tilgangi að auka stuðning og skapa sátt við pólitískar hugmyndir og aðgerðir. Með pessum hætti beita stjórnmálamenn ákveðnum skilgreiningum og hugtökum frekar en öðrum til að lýsa og „merkja“ fyrirbæri í orðræðunni. Pau hugtök sem stjórnmálamenn halda uppi í almennri umræou parf pví að greina í félagslegu og pólitísku ljósi. pessi grein byggir á orðræðugreiningu á hugtakanotkun stjórnmálamanna sem unnin var úr spurningalistakönnun Félagsvísindastofnunar Háskóla Íslands. par var skoðaður munur á viðhorfum almennings til priggja (mis)mikilvægra málefna í íslenskum samtíma, par sem einn hópur fékk spurningu um málefni með „hlutlausu“ hugtaki en annar hópur fékk spurningu um sama málefni með „gildishlöðnu“ hugtaki. Tilgáturnar gerðu ráð fyrir að hlutlausari hugtök hlytu meiri stuðning heldur en gildishlaðnari hugtök. Nánar tiltekið var spurt um viðhorf til: a) lögleiðingar spilahalla eða spilavita hér á landi; b) setningu veggjalda eða vegtolla á pjóðvegum landsins; og c) nýrra laga um pungunarrof eða fóstureydingar. Niðurstöðurnar sýndu að viðhorf til málefnanna priggja voru mismunandi en bentu jafnframt til pess að hugtakanotkun skipti ekki miklu máli í pessu samhengi. Lítill og ómarktækur munur var á viðhorfum svarenda til lögleiðingar spilahalla eða spilavíta, sem og til laga um pungunarrof eða fóstureyðingar (tengslin voru frekar í öfuga átt við pað sem spáð var), en marktækur munur kom fram á viðhorfum svarenda sem studdu frekar setningu veggjalda en vegtolla. Niðurstöðurnar benda til pess að útbreiðsla hugtaka og hugtakalæsi almennings skipti máli í pessu samhengi.
\end{abstract}

\author{
Icelandic Review of Politics and Administration Vol. 16, Issue 2 (105-124) \\ (C) 2020 Contact: Viðar Halldórsson, vidarh@hi.is \\ Article first published online December 17th 2020 on http://www.irpa.is \\ Publisher: Institute of Public Administration and Politics, Gimli, Sæmundargötu 10, 102 Reykjavík, Iceland \\ Stjórnmál \& stjórnsýsla 2. tbl. 16. árg. 2020 (105-124) Fræđigreinar \\ (c) 2020 Tengiliður: Viðar Halldórsson, vidarh@hi.is \\ Vefbirting 17. desember 2020 - Birtist á vefnum http://www.irpa.is \\ Útgefandi: Stofnun stjórnsýslufræđa og stjórnmála, Gimli, Sæmundargötu 10, 102 Reykjavík \\ DOI: https://doi.org/10.13177/irpa.a.2020.16.2.2 \\ This work is licensed under a Creative Commons Attribution 3.0 License.
}


Efnisorð: Félagsfræði pekkingar; orðræðugreining; viðmiðabinding; hugtakalæsi.

\section{The effects of neutral versus value-laden concepts on public attitudes}

\section{Abstract}

Politicians deliver their messages through the use of language with the intention of creating public support for their ideas and actions. Politicians, therefore, apply certain concepts, in preference to others, to mark certain phenomena in a specific way in the common discourse. Therefore, concepts utilized by politicians need to be analyzed critically from a sociological and political perspective. This paper is built on a political discourse analysis of the strategic "normalization" of political concepts by Icelandic politicians. The Social Science Research Institute at the University of Iceland conducted a questionnaire survey on the attitudes of Icelanders towards three debated issues in contemporary Icelandic society: the legitimization of casinos, ways to finance major road constructions, and new laws on the abortion rights of women. To account for the effects of the politicians' utilization of concepts, half of the respondents received a question with a "neutral" concept and the other half got a question with a "value-laden" concept on each of the issues. The hypotheses assumed that the more neutral concepts would gain more general support than the more value-laden concepts. The results indicate that the attitudes towards the three issues were mixed and, furthermore, that the use of different concepts does not seem to make much of a difference, since only one hypothesis was supported, whereas the other two were rejected. It can also be argued that the circulation of concepts and the conceptual literacy of the public are important issues in this context.

Keywords: Sociology of knowledge; political discourse; normalization; conceptual literacy.

\section{Inngangur}

„Takmörkun tungumálsins afmarkar heimsýn mína.“

(Wittgenstein [1921]/2001, 5.6)

Pólitísk orðræða mótar og stýrir almennri umræðu (Foucault 1973; van Dijk 2002). Tungumálið gegnir par lykilhlutverki pví skilaboðum stjórnmálamanna er miðlað gegnum tungumálið í peim tilgangi að vekja athygli á, auka stuðning við, eða skapa sátt við pólitískar hugmyndir og aðgerðir stjórnmálamanna og annarra áhrifahópa innan samfélaga (Perinbanayagam 2018). Tungumálið mótar jafnframt hugsanir og viðhorf fólks sem sýnir sig í pví að fólk með ólík tungumál hefur mismunandi skilning á sömu fyrirbærum (Bloom 1981; Hoffman, Lau \& Johnson 1986; van Dijk 2002; Vigotsky 1962). Veruleikinn er pví félagslega skapaður (Berger \& Luckmann [1967]/1991). Par af leiðir að stjórnmálamenn beita ákveðnu tungutaki, og nota tilteknar skilgreiningar og hugtök 
öðrum fremur til að lýsa og „,merkja“ fyrirbæri á viðeigandi hátt, í peim tilgangi að skapa ákveðin hugrenningatengsl meðal borgaranna, hugmyndum og málum sínum til framdráttar (Chong \& Druckman 2007; Freedman 2013, 433-56; Zerubavel 2018). Með pessum hætti byggir slík orðræða á aðgengi að valdi par sem peir sem völdin hafa geta haft áhrif á hvaða hugtakanotkun er beitt um málefni, fest í lög og pannig öðlast sess til lengri tíma sem raunveruleg merking fyrirbærisins (Focault [1969]/1982; Merton [1945]/1996; White 2007). Tungumálið og hugtökin sem stjórnmálamenn koma á framfæri í almennri umræðu, sem og í lagasetningum, parf pví að greina í félagslegu og pólitísku ljósi.

Dessi grein byggir á orðræðugreiningu (e. discourse analysis) stjórnmálanna og tekur með peim hætti fyrir prjú dæmi um hvernig íslenskir stjórnmálamenn hafa með markvissum hætti beitt tilteknum hugtökum til að lýsa ákveðnum fyrirbærum um (mis)mikilvæg málefni samtímans með pað fyrir augum að hafa áhrif á viðhorf almennings til málefnanna. Nánar tiltekið, leitast greinin við að greina viðhorf almennings til priggja málefna eftir pví hvort notast er við „hlutlaust“ eða „gildishlaðið“ hugtak í spurningunum um málefnin (sjá Chong \& Druckman 2007). Málefnin prjú snúa að: 1) hvort leyfa eigi spilahallir eða spilavíti á Íslandi; 2) hvort stuðningur sé við setningu veggjalda eða vegtolla á pjóðvegum landsins; og 3) hvort svarendur séu fylgjandi nýlegum lögum um pungunarrof eða fóstureyðingar. Markmið greinarinnar eru pví annars vegar að greina viðhorf almennings til málefnanna priggja sem um ræðir, og hins vegar að kanna hvort munur sé á viðhorfum almennings til málefnanna eftir pví hvaða hugtökum er beitt í spurningunum hverju sinni.

Gögnin sem notast er við eru úr könnun sem Félagsvísindastofnun Háskóla Íslands sendi út fyrir höfund greinarinnar á netpanelhóp stofnunarinnar í byrjun árs 2020. Spurt var um viðhorf til peirra priggja málefna sem nefnd eru hér að framan og fengu pátttakendur af handahófi mismunandi hugtök í sömu spurningunum. Đ.e. helmingur svarenda fékk til að mynda spurningu par sem spurt var um hvort leyfa ætti spilavíti á Íslandi og fékk hinn helmingur svarenda spurningu um hvort leyfa ætti spilahallir á Íslandi. Leitast var við að skoða hvort almennari og síður gildishlaðin hugtök nytu meiri stuðnings svarenda en hugtök sem hafa prengri og neikvæðari blæ eða merkingu. Lagt var upp með eftirfarandi tilgátur:

- Meiri stuðningur er við að leyfa spilahallir hér á landi heldur en spilavíti

- Meiri stuðningur er við setningu veggjalda á pjóðvegum landsins heldur en vegtolla

- Meiri stuðningur er við nýleg lög sem víkkuðu rétt kvenna til pungunarrofs heldur en fóstureydinga

\section{Hugtakanotkun orðræðunnar}

Félagsfræði pekkingar (e. sociology of knowledge) er leiðardæmi innan félagsfræðilegra kenninga sem byggir á peirri grunnhugmynd að veruleiki okkar mannfólksins sé félagslega byggður (Berger \& Luckmann [1967]/1991). Í gegnum hversdagslegar venjur lærum við hvernig við sjáum heiminn, skiljum hann, túlkum hann og hegðum okkur í 
honum. Lærð hegðun mótar veruleika okkar og pví getur veruleiki eins verið frábrugðinn veruleika annars. Menningarlegur munur milli hópa verður pví enn ápreifanlegri en ella par sem mismunandi pekking verður til og er viðhaldið, frá einum stað til annars. Félagsfræði pekkingar beinir pví sjónum að hinum félagslega uppruna pekkingar:

Rekja má uppruna félagsfræði pekkingar til peirrar merku tilgátu að jafnvel sannindi ættu að teljast byggð á félagslegum grunni og tengd sögu pess samfélags sem pau eru sprottin úr (Merton [1945]/1996, 207). ${ }^{2}$

Félagsfræðingar á borð við Durkheim ([1915]/1965), Mead ([1934]/1972), Foucault (1973) og Bourdieu ([1983]/1991) hafa til að mynda bent á hvernig tungumálið spilar lykilhlutverk í félagslegri byggingu veruleikans par sem við skynjum og hugsum um heiminn, meðvitað og ómeðvitað, í gegnum pau orð og hugtök sem eru ráðandi í menningunni hverju sinni. Orð og orðskilningur gerir okkur mannfólkinu pví kleift að tjá okkur, eiga samskipti og skilgreina okkur sjálf og veruleikann í kringum okkur. Hugtökin sem við gefum fyrirbærum eiga sér rætur í sameiginlegum menningar- og reynsluheimi fólks sem notast við sömu hugtök yfir sömu fyrirbæri. Peir sem skilja og tala sama tungumál og/eða koma úr sama menningarheimi, mótast pví á svipaðan hátt af notkun tungumálsins og hafa pví oft svipaða sýn á veruleikann. Merking hugtaka er pví skýrari og sameiginlegri meðal peirra sem tala sama tungumál heldur en annarra (Vigotsky 1962). Í gegnum tungumálið, og pau hugtök sem við gefum fyrirbærum og beitum svo í daglegu tali, öðlumst við ákveðinn skilning á fyrirbærum.

Michael Polanyi hefur í pessu samhengi fjallað um hvernig maðurinn getur ekki eingöngu treyst á sjálfan sig til að afla sér pekkingar heldur parf hann að treysta öðrum aðilum, og pá oft á tíðum félagslegum stofnunum, fyrir áreiðanlegum og réttmætum upplýsingum um ýmis málefni (Polanyi [1959]/2014). Michel Foucault hélt pví enn fremur fram að tungumálið væri aldrei hlutlaus miðill heldur stjórnaðist orðræða tungumálsins alltaf af valdaskipulagi samfélaga. Framleiðsla pekkingar væri pannig í höndum peirra sem hefðu vald og aðgang að pekkingu og miðluðu henni út í samfélagið par sem hún dreifist um félagsleg net par til hún verður almenn og viðurkennd. Slík viðmiðabinding tungumálsins (e. normalization of language) felur í sér að í gegnum félagslega ferla formbindast hugmyndir um hvað sé rétt og eðlilegt í gegnum tungumálið (Foucault [1975]/1979). Með pessum hætti festast ákveðin orð og hugtök í sessi og fara að virka sem náttúrulegar og gefnar staðreyndir um fyrirbæri, frekar en félagslega mótaðar hugmyndir ráðandi afla (Foucault [1975]/1979; Galbraith 1962). Hugtökin sem við notum til að skilgreina veruleikann má pannig líta á sem útsmogið pólitískt afl (Chong \& Druckman 2007; Polanyi [1958]/1998). Orðræðan sem mynduð er skilyrðir borgarana til ómeðvitaðrar hlýðni með pví að setja fram skilgreiningar og viðmið um hegðun og viðhorf peirra, en jaðarsetur á sama tíma pá sem gangast ekki við pessum viðmiðum (Durkheim [1938]/1962; Foucault 1973; White 2007). Félagsleg viðmið (e. social norms), eins og myndast í gegnum tungumálið, gegna pannig mikilvægu hlutverki í að viðhalda ríkjandi valdajafnvægi/valdaójafnvægi samfélaga (Zerubavel 2018). 


\section{STJÓRNSÝSLA}

Í staðleysuskáldsögu sinni 1984 lýsti bandaríski rithöfundurinn George Orwell pví hvernig ráðandi öfl breyttu tungumálinu úr gamlensku (e. Oldspeak) í nýlensku (e. Newspeak) í peim tilgangi að hafa áhrif á hugsun og heimssýn borgaranna. Nýlenskan var með pessum hætti tilraun stjórnvalda til að stjórna hugsun almennings með pví að breyta merkingu orða (e. thought control), deyfa hefðbundin hugsanatengsl orða og hugtaka, og prengja sýn í takt við vilja ráðandi stjórnvalda.

Orðaforði B samanstóð af orðum sem höfðu verið mynduð gagngert í pólitískum tilgangi: p.e. orðum sem ekki bara lumuðu sí og æá einhvers konar pólitískri tengingu eða tilvísun, heldur gegndu beinlínis pví hlutverki að pröngva æskilegum skoðunum og viðhorfum upp á notendur sína (Orwell [1949]/2003, 347). ${ }^{3}$

Pessi skáldskapur Orwells frá miðri síðustu öld stillir upp frekar ógnvekjandi mynd af pví hvernig stjórnvöldum er í lófa lagið að (mis)nota tungumálið í pólitískum tilgangi með peim hætti að móta skynjun og skilning borgaranna til stuðnings við ráðandi hugmyndir (Perinbanayagam 2018; Zembylas 2010). Stjórnmálamenn fóru, frá og með sjöunda áratug síðustu aldar, að nýta sér tungumálið með markvissari hætti en áður (Chong \& Druckman 2007; Freedman 2013, 436) og hafa hagsmunaverðir stjórnmálanna (e. lobbyist) meðal annars lagt til að stjórnmálamenn noti einfalt og hversdagslegt mál í peim tilgangi að ná sem breiðastri samstöðu um málefni (Zetter 2014). Mörg peirra hugtaka sem búin eru til eða er haldið markvisst fram af stjórnmálamönnum geta pannig skotið rótum í tungumálinu, fest sig í sessi - með beinum og óbeinum hætti (Polanyi [1958]/1998) - og öðlast með pví móti réttmæti í hugum fólks um að fyrirbærið tákni/ merki nákvæmlega „petta“ en ekki „eitthvað annað.“ Hugtökin eru pví takmarkandi, pví að á sama tíma og við öðlumst ákveðinn skilning á fyrirbærum í gegnum hugtök, takmarka hugtökin einnig skilning okkar á pessum sömu fyrirbærum. Howard S. Becker hefur í pessu samhengi enn fremur bent á að pað að skilgreina fyrirbæri út frá tilbúnum hugtökum hefur pær afleiðingar að prengja sýn á viðfangsefnin og koma hugtökin sem slík pví jafnvel í veg fyrir heildrænni skilning okkar á pessum sömu viðfangsefnum (2007, 214). Við eigum pví oft erfitt með að sjá út fyrir pað sem hugtökin sjálf fela í sér og skilja pannig meira en okkar lærði skilningur á hugtökunum segir okkur fyrir um. Af pessu leiðir að hugtökin sem við smíðum um fyrirbæri móta skynjun okkar og skilning, en geta að sama skapi takmarkað skilning okkar á pessum tilteknu fyrirbærum. Í almennri orðræðu geta hugtök pví nýst sem nokkurs konar vopn í pólitískum og hugmyndafræðilegum átökum milli hópa í umræðu um ákveðin fyrirbæri. Edelman heldur pví fram að ef ekki væru átök um merkingu hlutanna, sem byggja jafnan á ólíkum hagsmunum og vantrausti milli hópa samfélagsins, væru málefnin í eðli sínu ekki pólitísk (1988, 104). Баð skiptir pví máli hvaða nafni hlutir eru kallaðir (Becker 2007).

Orðræðan er mótuð af pví félagslega og pólitíska samhengi sem ríkir hverju sinni og getur orðræðan pví öðlast táknrænt lögmæti og áunnið sér sess sem réttmæt lýsing á fyrirbærum. Tungumálið endurspeglar pannig jafnan hugmyndir peirra sem valdið hafa 
(Bourdieu [1983]/1991; Foucault [1975]/1979; Lessig 1995; Zerubavel 2018) og hefur til að mynda verið notað til að styðja ríkjandi hugmyndir um yfirráð karla yfir konum (Lessig 1995), yfirráð hvítra yfir svörtum (White 2007), og ófatlaðra yfir fötluðum (Zerubavel 2018) svo dæmi séu tekin. Með peim hætti fá sum orðin í tungumálinu sérstaka merkingu (e. marked) til merkis um að pau séu frávik frá hinu eigindlega á meðan önnur orð eru ómerkt (e. unmarked) til marks um að pau tákni eðlilegt ástand - til dæmis hvernig við notum orðið maður sem norm og kona sem frávik frá norminu (Zerubavel 2018). Orð og hugtök virka pví sem nokkurs konar kóðuð skilaboð (e. coded text) og fá pannig félagslega merkingu (e. social meaning) sem gagnast einum málstað fremur en öðrum (Chong \& Druckman 2007; Khoo 2017; Lessig 1995).

Með pessum hætti verða sum hugtök gildishlaðin (p.e. orð sem eru hlaðin aukinni merkingu) en önnur ekki. Gildishlaðin hugtök eru að finna víða í orðræðunni eins og til dæmis pegar talað er á niðrandi hátt um jaðarhópa samfélagsins - og bent hefur verið á í pví sambandi að hræðslu- og hatursorðræða hafi aukist á undanförnum árum par sem ýmsar hreyfingar gera markvisst út á gildishlaðna orðræðu í garð ýmissa minnihlutahópa eins og flóttamanna og innflytjenda svo dæmi séu tekin (Chomsky 2018; Gore 2017; Revelli 2019). Í peim tilgangi að draga úr misrétti, kúgun fordómum og félagslegri stimplun hefur réttindabarátta nútímans skorað margar pessar venjur tungumálsins á hólm. Pess er krafist að venjubundin orðnotkun notist ekki við gildishlaðin orð og hugtök sem kunna að viðhalda kerfisbundnu misrétti ýmissa hópa innan nútíma samfélaga. Af pessu leiðir að endurinnrömmun hugtaka getur falið í sér félagslegar breytingar (Freedman 2013, 434).

Málefni er jafnan hægt að skoða frá mörgum hliðum og hafa Chong og Druckman (2007) fjallað sérstaklega um hvernig stjórnmálamenn nýta sér tungumálið með markvissum hætti til pess að ramma orðræðuna inn á ákveðin hátt í peim tilgangi að hafa áhrif á viðhorf borgaranna (e. framing effects). Stjórnmálamenn geta pví nýtt sér slíka innrömmunartækni til að endurskilgreina málefni með nýjum hugtökum, og jafnvel í jákvæðara ljósi en tíðkast, til að mynda í lagafrumvörpum (sjá einnig Fairhurst 2011; Goffman 1974). Hvort umrætt hugtak virkar jákvætt eða neikvætt á fólk, hvort pað er á einhvern hátt gildishlaðið eða ekki getur pví skipt miklu máli ef litið er til afstöðu fólks til málefnisins. Pannig geta hefðbundin málefni með neikvæða skírskotun endurbirst í umræðunni sem jákvæð par sem gefið er til kynna að pau geti falið í sér ný tækifæri. Samtal ráðandi aðila, sem og stjórnmálamanna við almenning fer fyrst og fremst fram í gegnum fjölmiðla. Ráðandi aðilar reyna pví að hafa áhrif á orðræðuna í gegnum fjölmiðla með pví að miðla til peirra „réttu“ hugtökunum yfir fyrirbæri sem gagnast peim í umræðunni hverju sinni, en fjölmiðlar samkvæmt Hermann og Chomsky (1988) spila jafnan með peim sem völdin hafa og miðla pví orðræðu stjórnmálanna til almennings.

Til pess að greina merkingu, tilgang og afleiðingar pólitískrar hugtakanotkunar hafa fræðimenn notast við orðræðugreiningu (e. political discourse analysis) (van Dijk 2002). Pólitísk orðræðugreining felur í sér að leitast er við til að skoða og greina skilaboð stjórnmálamanna í gegnum tungumálið með fjölbreyttum hætti (Dunmire 2012). Hagsmunaaðilar í stjórnmálum hér á landi - í víðri merkingu pess orðs - beita jafnan pólitískri hugtakanotkun í almennri umræðu um hin ýmsu málefni, meðal annars með pví að búa til 
ný hugtök um fyrirbæri sem pekktari hafa verið undir öðrum nöfnum, væntanlega með pað að markmiði að hafa áhrif á viðhorf almennings til málefnanna. Til að mynda reyna flutningsmenn lagafrumvarpa gjarnan að afmarka hugtök sem talin eru neikvætt gildishlaðin á hlutlausari hátt en jafnan er gert með pví að gefa peim ný nöfn og setja í nýjan búning til að auka stuðning og ná almennri sátt um frumvörpin. Í pessari grein verður leitast við að kanna hvort endurskilgreining hugtaka, og/eða meðvituð hugtakanotkun stjórnmálanna, hafi áhrif á viðhorf almennings til nokkurra álitamála íslensks samtíma með pví að greina viðhorf til sömu málefna út frá spurningum par sem mismunandi hugtökum er beitt, annars vegar almennara hugtaki og hins vegar gildishlaðnara hugtaki.

\section{Aðferð, breytur og gagnagreining}

Til að skoða viðhorf almennings til nokkurra samfélagslegra álitamála, sem og að meta áhrif mismunandi hugtakanotkunar á viðhorf almennings var framkvæmd spurningalistakönnun úr pýði íslensku pjóðarinnar. Félagsvísindastofnun Háskóla Íslands sá um framkvæmd könnunarinnar í byrjun árs 2020. ${ }^{4}$ Nánar tiltekið, fór gagnaöflun fram 11. febrúar til 8. mars og náði könnunin til 1954 meðlima í netpanel Félagsvísindastofnunar; byggt var á lagskiptu tilviljunarúrtaki. Alls bárust 987 svör og var pátttökuhlutfall pví 50,5\%.

Könnunin byggir á mælingum á viðhorfum til eftirfarandi priggja pátta: afstöðu svarenda til spilahalla/spilavíta; veggjalda/vegtolla; og til pungunarrofs/fóstureyðinga. Aðferðin sem notast er við byggir á einföldu tilraunasniði par sem upprunalega úrtaki könnunarinnar var skipt í tvennt fyrir hvern spurningaflokk, sem mynduðu pannig tvo tilraunahópa í hverjum spurningaflokki og fékk annar hópurinn spurningu með „hlutlausu“ hugtaki en hinn hópurinn fékk spurningu með „gildishlöðnu“ hugtaki. ${ }^{5}$

\section{Spilahallir/spilavíti}

Fjárhættuspil eru gjarnan stunduð í svokölluðum spilavítum. Nútímamálsorðabók stofnunar Árna Magnússonar skilgreinir spilavíti sem skemmtistaði par sem fjárhættuspil eru stunduð (Íslensk nútímamálsorðabók 2020a). Viðskeytið víti stendur í pessu samhengi fyrir merkinguna helviti. Spilavíti má pví í sögulegu ljósi túlka sem neikvætt gildishlaðið hugtak par sem margir fara halloka við slíka iðju sem getur leitt til spilafíknar og ýmissar mannlegrar ógæfu (Adams 2007). Orðið spilahöll er aftur á móti ekki að finna í íslenskum orðabókum. En viðskeytið böll merkir jafnan stórhýsi í orðabókum. Đað er pví talsverður munur á hugtökunum víti og höll í pessu samhengi. Á löggjafarpingi Alpingis árin 2014 - 2015 stóðu prettán pingmenn að frumvarpi til laga um lögleiðingu slíkrar starfsemi hér á landi, par sem spiluð eru fjárhættuspil sem áttu að eiga sér stað innan spilahalla en ekki spilavíta (Frumvarp til laga um spilahallir 2015). Dví er spurt annars vegar um viðhorf almennings til pess að leyfa spilahallir og hins vegar að leyfa spilavíti:

1. Hversu fylgjandi eða andvíg/ur ertu pví að leyfa spilahallir (spilasali par sem spiluð eru fjárhættuspil) hér á landi? ( $\mathrm{N}=475)$

2. Hversu fylgjandi eða andvíg/ur ertu pví að leyfa spilavíti (spilasali par sem spiluð eru fjárhættuspil) hér á landi? ( $\mathrm{N}=497)$ 


\section{Veggjöld/vegtollar}

Talsverð umræða hefur að undanförnu átt sér stað um hvernig eigi að fjármagna ýmsar vegaframkvæmdir á pjóðvegum landsins. Í umræðunni hefur annars vegar verið rætt um setningu veggjalda og hins vegar um setningu vegtolla til að standa straum af slíkum kostnaði. Í skýrslu Stjórnarráðsins um málefnið frá 2019 er til að mynda mælt með setningu veggjalda í pessu samhengi fremur en vegtolla (Stjórnarráo Íslands 2019). Vegtollar eru einungis nefndir í skýrslunni pegar dæmi eru tekin af fjármögnun vegaframkvæmda annarra pjóða en ekki hér innanlands. Í orðabókum er iðulega talað um gjöld sem borgun fyrir verk eða sem skatt, en tolla sem gjald sem lagt er á vöru sem flutt er á milli ríkja (Íslensk nútímamálsorðabók 2020b). Hugtökin hafa pví að upplagi ólíka orðabókarmerkingu. Íslensk Samheitaorðabók greinir hugtökin pó aftur á móti sem samheiti (Svavar Sigmundsson 2012). Баð er pví ekki alltaf greinanlegur munur á peirri hugtakanotkun sem beitt er pegar rætt er um gjöld eða tolla. Баð kann að vera að almenningur tengi hugtakið tollur í pessu samhengi við svokallaða tollheimtumenn eða uppsetningu tollahliða á pjóðvegum landsins (e. tollbooths) eins og pekkjast sums staðar erlendis, sem virkar meira afgerandi aðgerð heldur en hugtakið veggjöld sem hefur almennari merkingu í orðræðunni. Dví er leitast við að athuga hvort pað skipti máli hvort talað er um veggjöld eða vegtolla í pessu samhengi með eftirfarandi spurningum:

a) Hversu fylgjandi eða andvíg/ur ertu setningu veggjalda á pjóðvegum Íslands? $(\mathrm{N}=483)$

b) Hversu fylgjandi eða andvíg/ur ertu setningu vegtolla á pjóðvegum Íslands? $(\mathrm{N}=472)$

\section{Dungunarrof/fóstureyding}

Um mitt ár 2019 voru sampykkt á Alpingi ný lög sem víkka út rétt kvenna til að binda endi á eigin meðgöngu. Í lögunum, sem og í orðræðu í kringum lagasetninguna var gjarnan talað um nýyrðið pungunarrof í stað hefðbundna hugtaksins fóstureyðing - en pað hugtak er meðal annars notað pegar slíkrar pjónustu er krafist á heimasíðu Landlæknis (Landlæknir 2020). Frumvarpið tekur sérstaklega fram að breyta purfi hugtakinu; tala ekki um fóstureyðingu, sem er að mati frumvarpsins gildishlaðið hugtak með harðneskjulegan og neikvæðan blæ, heldur taka upp hugtakið pungunarrof, sem pykir hlutlausara (Frumvarp til laga um pungunarrof 2019, 3). Hugtakið pungunarrof er pó til að mynda ekki að finna í Nútímamálsorðabók stofnunar Árna Magnússonar. Dví er leitast við að athuga hvort pað skipti máli hvort talað er um pungunarrof eða fóstureyðingar í pessu samhengi með eftirfarandi spurningum:

a) Hversu fylgjandi eða andvíg/ur ertu nýlegum lögum sem víkkuðu rétt kvenna til pungunarrofs, úr 16 vikum í 22 vikur? $(\mathrm{N}=464)$

b) Hversu fylgjandi eða andvíg/ur ertu nýlegum lögum sem víkkuðu rétt kvenna til fóstureyðinga, úr 16 vikum í 22 vikur? $(\mathrm{N}=471)$ 
Til að prófa fyrrnefndar tilgátur sem lögðu upp með að meiri stuðningur væri við: að leyfa spilahallir hér á landi heldur en spilavíti, setningu veggjalda á pjóðvegum landsins heldur en vegtolla, og lög sem víkkuðu rétt kvenna til pungunarrofs heldur en fóstureydinga, fengu pátttakendur í könnuninni sömu spurningu með mismunandi hugtaki. Með hliðsjón af ofangreindu var til dæmis helmingur úrtaksins spurður hvort leyfa ætti spilahallir og helmingur var spurður hvort leyfa ætti spilaviti. Detta var gert í peim tilgangi að meta hvort orðalag hugtaksins hefði áhrif á viðhorf til málefnisins. Spurningarnar sex (um málefnin prjú) voru allar mældar á 7 punkta raðkvarða með svarkostunum: algjörlega fylgjandi, mjög fylgjandi, frekar fylgjandi, hvorki fylgjandi né andvíg/ur, frekar andvíg/ ur, mjög andvíg/ur, algjörlega andvíg/ur. Svarendur fengu spurningar í handahófskenndri röð.

Jafnframt var notast við eftirtaldar bakgrunnsbreytur við frekari greiningu gagnanna: kyn $(1=\mathrm{kk}, 2=\mathrm{kvk})$, aldur (1=18-29 ára, 2= 30-44 ára, 3= 45-59 ára, 4= 60 ára og eldri), búseta (1=höfuðborgarsvæði, 2= landsbyggð), menntun (1= grunnskólamenntun, 2= framhaldsskólamenntun, $3=$ háskólamenntun), fjölskyldutekjur $(1=400.000$ kr. eða lægri, $2=401-600.000 \mathrm{kr} ., 3=601-900.000 \mathrm{kr} ., 4=901-1.300 .000 \mathrm{kr} ., 5=$ hærri en 1.300 .000 kr.), og stjórnmálaskoðun, sem mæld var með spurningunni „Í stjórnmálum er stundum talað um hægri og vinstri. Hvar myndirðu staðsetja pig á kvarða frá 0 til 10, par sem 0 er lengst til vinstri og 10 lengst til hægri?” (0-10).

Gögnin voru greind með: lýsandi tölfræði, til að gera grein fyrir stöðunni; fjölbreytu aðhvarfsgreiningu, til að greina frekar samband ýmissa bakgrunnsbreyta við stuðning við málefnin sem og hvort hugtakanotkun í spurningum hafi áhrif á samböndin; og t-prófum, til að meta hvort munur væri á viðhorfum ýmissa pjóðfélagshópa til málefnanna eftir mismunandi hugtakanotkun í spurningunum.

\section{Niðurstöður}

\subsection{Stuðningur við málefnin}

Stuðningur við málefnin prjú sem spurt var um í könnuninni; hvort leyfi eigi spilahallir/ spilavíti hér á landi, hvort stuðningur sé við setningu veggjalda/vegtolla á pjóðvegum landsins, eða hvort stuðningur sé við lög um pungunarrof/fóstureyðingar sem tóku gildi árið 2019, reynist mismunandi (Mynd 1). 


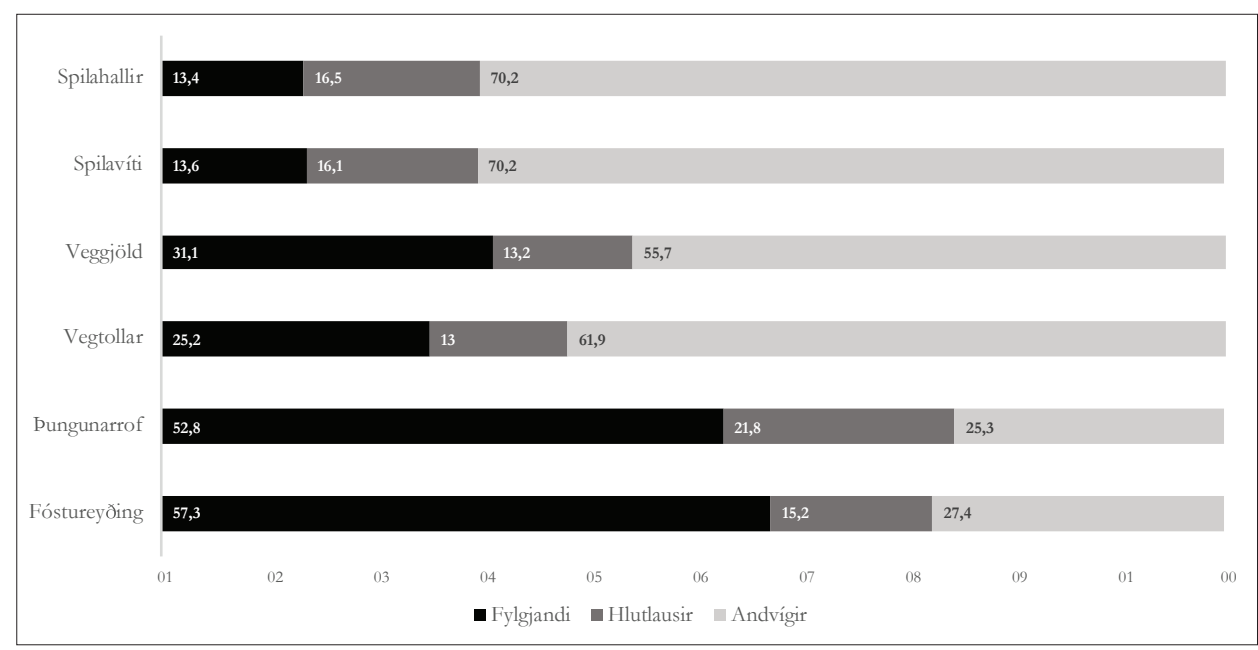

Mynd 1. Við̆horf til málefnanna priggja. Hlutfall svarenda sem voru fylgjandi, hlutlausir, eđa andvígir

Eins og sjá má á Mynd 1 pá er mestur stuðningur er við ný lög um pungunarrof/fóstureyðingar par sem í kringum 55\% svarenda eru peim fylgjandi en um fjórðungur eru lögunum andvígir. Á milli 25-30\% svarenda eru fylgjandi setningu veggjalda/vegtolla á pjóðvegum landsins en hátt í 60\% andvígir. Ríflega 13\% svarenda eru svo fylgjandi lögleiðingu spilahalla/spilavíta hér á landi á meðan um 70\% svarenda eru pví andvígir.

pegar stuðningur við málefnin er greindur frekar (með fjölbreytu aðhvarfsgreiningu) má sjá að pað eru helst karlar ( $b=.160 / b=.250)$, peir sem yngri eru $(b=.195 / b=.337)$ og peir sem staðsetja sig á hægri væng stjórnmálanna $(b=-.154 / b=-.255)$ sem eru fremur fylgjandi lögleiðingu spilahalla/spilavíta hér á landi heldur en aðrir, sama hvort hugtakið var notað í spurningunni (sjá Töflu 1). Deir sem styðja setningu veggjalda/vegtolla á pjóðvegum landsins eru helst peir sem hafa miklar heimilistekjur $(b=-.199 / b=-.118)$. Höfuðborgarbúar ( $b=.104)$ og peir sem skilgreina sig á hægri væng stjórnmálanna ( $b=-$ .104) eru auk pess ívið líklegri til að styðja setningu veggjalda en aðrir, en aftur á móti eru peir sem eru með meiri menntun $(b=-159)$ líklegri en aðrir til að styðja setningu vegtolla á pjóðvegum landsins (sjá Töflu 2). Að lokum má sjá að pað er almennt frekar yngra fólk en eldra sem styður ný lög um pungunarrof/fóstureyðingar ( $b=.266 / b=.412)$. Jafnframt eru peir sem hafa meiri menntun $(b=-.253)$ sem og peir sem skilgreina sig á miðju eða vinstri væng stjórnmálanna ( $b=.167)$ líklegri til að styðja lög um pungunarrof, en peir tekjuhærri ( $b=-.143)$ eru aftur á móti líklegri til að styðja lög um fóstureyðingar (sjá Töflu 3). 
Tafla 1. Niðurstöđur aðhvarfsgreiningar úr spurningum um hvort leyfa eigi spilahallir/spilavíti

\begin{tabular}{|c|c|c|c|c|c|c|c|c|c|c|c|c|}
\hline & \multicolumn{6}{|c|}{ Spilahallir } & \multicolumn{6}{|c|}{ Spilavíti } \\
\hline & $\mathrm{B}^{*}$ & $\begin{array}{l}\text { Stađal- } \\
\text { villa }\end{array}$ & $t$ & P. & Neđri & Efri & $\mathrm{B}^{*}$ & $\begin{array}{c}\text { Staðal- } \\
\text { villa }\end{array}$ & $\mathrm{t}$ & P. & Neðri & Efri \\
\hline Fasti & & .508 & 7.789 & .000 & 2.959 & 4.959 & & .539 & 6.064 & .000 & 2.201 & 4.320 \\
\hline Kyn & .160 & .175 & 2.977 & $.003 * * *$ & .177 & .868 & .250 & .174 & 4.915 & $.000 * * *$ & .514 & 1.200 \\
\hline Aldur & .195 & .081 & 3.669 & $.000 * * *$ & .140 & .464 & .337 & .080 & 6.745 & $.000 * * *$ & .383 & .698 \\
\hline Búseta & .022 & .182 & .412 & .680 & -.283 & .433 & .079 & .179 & 1.573 & .117 & -.071 & .635 \\
\hline Menntun & .057 & .122 & .948 & .344 & -.125 & .356 & .010 & .114 & .188 & .851 & -.203 & .246 \\
\hline $\begin{array}{l}\text { Heimilis- } \\
\text { tekjur }\end{array}$ & .031 & .070 & .516 & .606 & -.102 & .174 & -.044 & .066 & -805 & .421 & -.184 & .923 \\
\hline $\begin{array}{l}\text { Stjórnmála- } \\
\text { kvarđi }\end{array}$ & -.154 & .038 & -2.883 & $.004^{* * *}$ & -.186 & -.035 & -.255 & .038 & -4.468 & $.000 * * *$ & -.242 & -.094 \\
\hline
\end{tabular}

Skýring: $\mathrm{R}^{2}=.11$, VIF: 1.059-1.358, Tol. $<0.1 . \mathrm{P} *<.10, * *<.05, \quad$ Skýring: $\mathrm{R}^{2}=.25$, VIF: 1.065-1.263, Tol. $<0.1 . \mathrm{P} *<.10$, $* * *<.001$.

$* *<.05, * * *<.001$

Tafla 2. Niðurstöður aðhvarfsgreiningar úr spurningum um hvort setja eigi veggjöld/vegtolla

\begin{tabular}{|c|c|c|c|c|c|c|c|c|c|c|c|c|}
\hline & \multicolumn{6}{|c|}{ Veggjöld } & \multicolumn{6}{|c|}{ Vegtollar } \\
\hline & $\mathrm{B}^{*}$ & $\begin{array}{c}\text { Stađal- } \\
\text { villa }\end{array}$ & $\mathrm{t}$ & P. & Neðri & Efri & $\mathrm{B}^{*}$ & $\begin{array}{c}\text { Stađal- } \\
\text { villa }\end{array}$ & $\mathrm{t}$ & P. & Neđri & Efri \\
\hline Fasti & & .592 & 9.180 & .000 & 4.270 & 6.598 & & .639 & 10.327 & .000 & 5.341 & 7.855 \\
\hline Kyn & -.031 & .203 & -.563 & .574 & -.514 & .285 & -.013 & .208 & -.221 & .825 & -.455 & .363 \\
\hline Aldur & -.015 & .092 & -.273 & .785 & -.206 & .156 & -.086 & .100 & $-1,558$ & .120 & -.352 & .041 \\
\hline Búseta & .104 & .212 & 1.947 & $.052^{*}$ & .004 & .830 & .053 & .211 & .945 & .345 & -.216 & .615 \\
\hline Menntun & .026 & .139 & .440 & .660 & -.212 & .333 & -.159 & .140 & $-2,624$ & $.009 * * *$ & -.645 & -.092 \\
\hline $\begin{array}{l}\text { Heimilis- } \\
\text { tekjur }\end{array}$ & -.199 & .079 & -3.341 & $.001 * * *$ & -.422 & -.109 & -.118 & .080 & $-1,891$ & $.060 *$ & -.309 & .006 \\
\hline $\begin{array}{l}\text { Stjórnmála- } \\
\text { kvarði }\end{array}$ & -.104 & .044 & -1.911 & $.057^{*}$ & -.172 & .002 & -.048 & .045 & -.844 & .400 & -.126 & .050 \\
\hline
\end{tabular}

Skýring: $\mathrm{R}^{2}=.07$, VIF: 1.023-1.274, Tol. $<0.1 . \mathrm{P} *<.10, * *<.05, \quad$ Skýring: $\mathrm{R}^{2}=.08$, VIF: 1.023-1.305, Tol. $<0.1 . \mathrm{P} *<.10$, $* * *<.001$.

$* *<.05, * * *<.001$

Tafla 3. Niðurstöður aðhvarfsgreiningar úr spurningum um stuðning við lög um pungunarrof/fóstureyđingar

\begin{tabular}{|c|c|c|c|c|c|c|c|c|c|c|c|c|}
\hline & \multicolumn{6}{|c|}{ Pungunarrof } & \multicolumn{6}{|c|}{ Fóstureyđingar } \\
\hline & $\mathrm{B}^{*}$ & $\begin{array}{l}\text { Stađal- } \\
\text { villa }\end{array}$ & $\mathrm{t}$ & P. & Neđri & Efri & $\mathrm{B}^{*}$ & $\begin{array}{l}\text { Stadal- } \\
\text { villa }\end{array}$ & $\mathrm{t}$ & P. & Neđri & Efri \\
\hline Fasti & & .591 & 4.236 & .000 & 1.340 & 3.664 & & .613 & 2.686 & .008 & .441 & 2.854 \\
\hline Kyn & .064 & .197 & 1.228 & .220 & -.145 & .629 & -.056 & .209 & $-1,037$ & .301 & -.627 & .194 \\
\hline Aldur & .266 & .094 & 5.132 & $.000 * * *$ & .297 & .666 & .412 & .094 & 7.942 & $.000 * * *$ & .564 & .936 \\
\hline Búseta & -.025 & .201 & $-0,481$ & .631 & -.492 & .299 & -.001 & .222 & $-0,015$ & .988 & -.441 & .434 \\
\hline Menntun & -.253 & .138 & $-4,349$ & $.000 * * *$ & -.871 & -.329 & .016 & .137 & .281 & .779 & -.231 & .308 \\
\hline $\begin{array}{l}\text { Heimilis- } \\
\text { tekjur }\end{array}$ & -.065 & .076 & $-1,131$ & .259 & -.236 & .064 & -.143 & .080 & $-2,471$ & $.014 * *$ & -.354 & -.040 \\
\hline $\begin{array}{l}\text { Stjórnmála- } \\
\text { kvarđi }\end{array}$ & .167 & .043 & 3.223 & $.001^{* * *}$ & .054 & .223 & .079 & .045 & 1,482 & .139 & -.022 & .156 \\
\hline
\end{tabular}




\subsection{Svör greind eftir mismunandi hugtakanotkun í spurningum}

pegar viðhorf til málefnanna priggja eru greind eftir pví hvaða hugtökum var beitt 1 spurningunum, p.e. hvort notast var við „hlutlaust“ eða „gildishlaðið“ hugtak (sjá Töflu. 4), pá má i fyrsta lagi sjá að ekki kom fram marktækur munur á peim sem tóku afstöðu til pess hvort leyfa ætti spilahallir annars vegar $(M=5.40, S E=1.59)$ eða spilavíti hins vegar $(\mathrm{M}=5.31, \mathrm{SE}=1.61)(\mathrm{t}$-.884). Tilgátu 1 er pví hafnað. Stuðningur við lögleiðingu spilahalla/spilavíta er almennt lítill samkvæmt niðurstöðunum og svipað hlutfall er fylgjandi og andvígt málefninu, sama hvort hugtakið var notað. Niðurstöðurnar sýna enn frekar að pað reyndist ekki vera merkjanlegur munur á neinum hópum í pá áttina að svarendur séu frekar fylgjandi „,hlutlausa“ hugtakinu (spilahallir) frekar en pví „gildishlaðna“ (spilavíti). Aftur á móti má sjá að pað eru marktækt fleiri í hópnum 30-44 ára (t -2.537**) og meðal peirra sem hafa hæstar tekjur ( $\left.\mathrm{t}-2.393^{* *}\right)$ sem styðja frekar lögleiðingu spilavíta en spilahalla, pvert á tilgátuna sem lagt var upp með. Með öðrum orðum, mismunandi hugtakanotkun virðist almennt ekki skipta miklu máli pegar svarendur eru spurðir hvort peir séu fylgjandi eða andvígir pví að leyfa spilahallir annars vegar, eða spilavíti hins vegar hér á landi pó svo greina megi mjög veikt (en ómarktækt) samband í öfuga átt við tilgátuna sem sett var fram.

Aftur á móti kemur fram marktækur munur eftir pví hvort svarendur eru fylgjandi setningu veggjalda $(\mathrm{M}=4.71, \mathrm{SE}=1.84)$ eða vegtolla $(\mathrm{M}=5.03, \mathrm{SE}=1.80)$ á pjóðvegum landsins (t $2.742 *$ ), par sem um $6 \%$ fleiri styðja veggjöld umfram vegtolla. Stuðningur við veggjöld fremur en vegtolla er stöðugur meðal nánast allra hópa svarenda og á peirri forsendu má halda pví fram að hugtakið veggjöld hafi breiðari og sterkari stuðning meðal almennings en hugtakið vegtollar. Til dæmis má sjá að marktækt fleiri svarendur af báðum kynjum (kk: t 1.984**; kvk: t 1.910*), í hópnum 30-44 ára (t 3.679***), peirra sem eru eingöngu með grunnskólamenntun (t 4.339***), peirra sem eru með lægstar heimilistekjur (t 2.606**) og peirra sem skilgreina sig til hægri í stjórnmálum (t 2.190**), voru frekar fylgjandi setningu veggjalda en vegtolla. Niðurstöðurnar staðfesta pví tilgátuna sem lagt var upp með.

Að síðustu má sjá að ekki kom fram marktækur munur á peim svarendum sem tóku afstöðu til pess hvort peir eru fylgjandi eða andvígir nýjum lögum um pungunarrof annars vegar ( $\mathrm{M}=3.32, \mathrm{SE}=1.92)$ eða fóstureyðingar hins vegar $(\mathrm{M}=3.25, \mathrm{SE}=2.00)(\mathrm{t}$ -.549). Munur á hópunum var um 4,5\% par sem fleiri svarendur voru fylgjandi lögum um fóstureyðingar heldur en pungunarrof, pvert á tilgátuna sem lagt var upp með í upphafi. En prátt fyrir að ekki komi fram marktækt samband eftir mismunandi hugtakanotkun í spurningunum má engu að síður greina áhugaverðar vísbendingar í niðurstöðunum. Til dæmis má sjá að stuðningur í sumum hópum virðist vera ívið meiri við við lög um fóstureyðingar en við lög um pungunarrof. Pannig virðast karlar ( $\mathrm{t}-1.006)$, sem og peir sem skilgreina sig til annað hvort til vinstri ( $t$-1.341) eða hægri ( $t$-1.316) í stjórnmálum vera líklegri til að vera fylgjandi lögum um fóstureyðingar en lögum um pungunarrof. Рað eru svo aftur á móti einna helst peir sem hafa lokið háskólamenntun ( $t$.864) sem virðast helst líklegri til að vera fylgjandi nýjum lögum um pungunarrof en fóstureyðingar. Munurinn á hópunum reyndist pó ekki vera tölfræðilega marktækur.

Samantekið pá er tilgátum 1 og 3 hafnað en tilgáta 2 stóðst. 


\section{Umræður}

Niðurstöðurnar á viðhorfum almennings til peirra priggja álitamála sem spurt var um í könnun Félagsvísindastofnunar sýna að mestur stuðningur er við ný lög um pungunarrof/fóstureyðingar par sem ríflega helmingur svarenda er fylgjandi nýju lögunum en um fjórðungur andvígur. Næstmestur stuðningur er við setningu veggjalda/vegtolla á pjóðvegum landsins; um 30\% svarenda eru pví fylgjandi en hátt í 60\% svarenda eru andvígir. Minnstur stuðningur er svo við lögleiðingu spilahalla/spilavíta hér á landi par sem á milli 13-14\% eru málefninu fylgjandi en um 70\% andvígir.

Með tilliti til tilrauna stjórnmálamanna til að viðmiðabinda ákveðin hugtök málum sínum til framdráttar og nota í pólitískri orðræðu (Foucault [1975]/1979) voru niðurstöðurnar greindar eftir mismunandi hugtakanotkun í spurningunum. Almennt sýna niðurstöðurnar að mismunandi hugtakanotkun stjórnmálamanna, p.e. hvort peir beiti „hlutlausum“ eða „gildishlöðnum“ hugtökum, hefur ekki mikil áhrif á viðhorf almennings. Niðurstöðurnar eru samt nokkuð misvísandi. Til dæmis sýna niðurstöður t-prófa að tilgáta 2 stóðst, par sem hugtakið veggjöld hafði meiri stuðning en hugtakið vegtollar, en tilgátur 1 og 3 stóðust hins vegar ekki par sem ekki er marktækur munur á peim sem eru annars vegar fylgjandi lögleiðingu spilahalla frekar en spilavíta og hins vegar peim sem eru fylgjandi lögum um pungunarrof fremur en fóstureyðingar. Samböndin í tilgátum 1 og 3 virðast jafnframt stefna í öfuga átt við tilgáturnar sem lagt var upp með. Niðurstöðurnar benda pví almennt til pess viðhorf almennings til málefnanna priggja séu frekar sterklega mótuð og byggi á gildismati borgaranna útfrá undirliggjandi félagslegum formgerðum (eins og kyni, aldri, búsetu, menntun, tekjum og stjórnmálaskoðunum) fremur en á orðræou dægurmálanna (sjá Chong \& Druckman 2007; Freedman 2013; Lessig 1995). Pannig má til að mynda sjá að samband ýmissa breyta, áðurnefndra bakgrunnsbreyta, við málefnin prjú er frekar stöðugt hvort sem spurt var um hlutlausara eða gildishlaðnara hugtak. Engu að síður má greina áhugaverðar vísbendingar um áhrif mismunandi hugtakanotkunar í gögnunum.

Fyrir pað fyrsta pá sýna niðurstöður aðhvarfsgreiningar að stuðningur við lögleiðingu spilahalla/spilavíta er mestur meðal karla, yngra fólks og peirra sem skilgreina sig til hægri í stjórnmálum, og skiptir pá engu máli hvort hugtakið er notað. Pá sýna niðurstöður t-prófa, sem framkvæmd voru til að meta nánar hvort munur væri á viðhorfum ýmissa pjóðfélagshópa til málefnisins eftir mismunandi hugtakanotkun í spurningunum, að enginn pjóðfélagshópur er líklegri til að vera fremur fylgjandi lögleiðingu spilahalla en spilavíta, eins og tilgátan gerði ráð fyrir, en svarendur á aldrinum 30-44 ára, sem og hæsti tekjuhópurinn eru marktækt líklegri til að vera frekar fylgjandi spilavítum en spilahöllum. Samkvæmt ofangreindu, benda niðurstöðurnar sterklega til pess að pað virðist nánast engu máli skipta hvort hugtakið spilahallir eða spilavíti eru notuð í umræðu um málefnið par sem nánast sami stuðningur mælist við málefnið, sama hvort hugtakið er notað.

Aftur á móti pá kemur fram marktækur munur á svörum við spurningum um setningu veggjalda annars vegar og vegtolla hins vegar, par sem fleiri eru fylgjandi setningu veggjalda fremur en vegtolla. Niðurstöður aðhvarfsgreiningar sýna að stuðningur við málefnið er mestur meðal peirra tekjuhærri (sama hvort hugtakið er notað), en íbúar 
höfuðborgarsvæðisins og peir sem skilgreina sig til hægri í stjórnmálum styðja frekar setningu veggjalda á meðan peir sem hafa meiri menntun styðja frekar setningu vegtolla. Niðurstöður aðhvarfsgreiningar benda par af leiðandi til pess að mismunandi hugtakanotkun hafi haft einhver áhrif á viðhorf ólíkra hópa til málefnisins. Niðurstöður t-prófa sýna enn frekar að karlar, konur, peir sem eru á aldrinum 30-44 ára, peir sem hafa eingöngu lokið grunnskóla, tekjulægsti hópurinn, og peir sem skilgreina sig til hægri í stjórnmálum styðja allir fremur setningu veggjalda en vegtolla á pjóðvegum landsins. Enginn pjóðfélagshópur styður aftur á móti setningu vegtolla fremur en veggjalda. Niðurstöðurnar eru pví afdráttarlausar og sýna að hugtakið veggjöld hefur meiri stuðning heldur en hugtakið vegtollar. Stuðningur við setningu veggjalda umfram vegtolla er í kringum 5,5\%.

Að síðustu sýna niðurstöður aðhvarfsgreiningar að pað eru helst yngri svarendur sem styðja ný lög um pungunarrof/fóstureyðingar. Peir svarendur sem hafa meiri menntun sem og peir sem skilgreina sig til vinstri í stjórnmálum eru líklegri til að styðja lög um pungunarrof en peir tekjuhærri eru líklegri til að styðja lög um fóstureyðingar. Samkvæmt pessu, gefa niðurstöður aðhvarfsgreiningar til kynna að yngri kynslóðirnar styðji helst málefnið, burtséð frá pví hvort hugtakið er notað í umræðunni en ólík hugtakanotkun virðist hafa einhver áhrif á viðhorf annarra hópa. Pegar litið er til niðurstaðna t-prófa vekur pað athygli að enginn pjóðfélagshópur er marktækt líklegri til pess að styðja lög um pungunarrof fremur en lög um fóstureyðingar, né heldur til að styðja lög um fóstureyðingar fremur en pungunarrof. Pessar niðurstöður gefa til kynna að mismunandi hugtakanotkun virðist ekki skipta máli í pessu samhengi.

Að pví sögðu sýna niðurstöðurnar samt sem áður að um 4,5\% fleiri styðja lög um fóstureyðingar fremur en lög um pungunarrof. Pó ekki hafi reynst marktækur munur á hópunum er engu að síður athyglisvert að sambandið virðist, ef eitthvað er, stefna í öfuga átt við pað sem spáð hafði verið par sem gildishlaðna hugtakið virðist njóta ívið meiri stuðnings heldur en hugtakið sem talið var hlutlausara. Af pessu má sjá að karlar og peir sem staðsetja sig á vinstri eða hægri væng stjórnmálanna, virðast vera ívið líklegri til að styðja lög um fóstureyðingar heldur en lög um pungunarrof (samböndin reyndust pó ekki vera tölfræðilega marktæk). Pessar vísbendingar í niðurstöðunum eru áhugaverðar. Eina hugsanlega skýringu á pessu neikvæða sambandi, sem gengur gegn tilgátunni, má rekja til hugtakalæsis (Chong \& Druckman 2007). Pannig má til að mynda sjá að svarendur í sumum hópum sem hvað helst styðja lög um fóstureyðingar (eins og karlar, yngstu aldurshóparnir, peir sem eru í lægsta tekjuhópnum, og peir sem skilgreina sig til vinstri í stjórnmálum), eru talsvert ólíklegri til að taka afstöðu til spurningar um pungunarrof (og svara bvorki nê) heldur en til spurningar um fóstureyðingar - ólíkt öðrum hópum (sjá Töflu V1 í viðauka). Niðurstöðurnar gefa pví til kynna að hugtakið pungunarrof kunni að vera óskýrt eða framandi fyrir suma, mun frekar en hugtakið fóstureyðing, og hafi par af leiðandi ekki tilætluð áhrif í pá átt að auka stuðning við málefnið. Pví getur pekking og reynsla svarenda af peim málefnum sem eru til umfjöllunar skipt allmiklu máli. Til dæmis er pungunarrof/fóstureyðing veigameiri hluti af reynsluheimi kvenna frekar en karla og pví má gera ráo fyrir að karlar séu ólíklegri en 
konur til pess að vera meðvitaðir um nýyrðið pungunarrof. Skilningur á hugtökum getur pannig verið mismunandi eftir hópum. Niðurstöðurnar benda pví til pess að hugtakið pungunarrof sé ekki búið að ná fótfestu í almennri umræðu meðal allra pjóðfélagshópa hér á landi enda eru tilmæli heilbrigðisráðherra um að taka upp hugtakið pungunarrof í stað hugtaksins fóstureyðing nýtilkomin (Frumvarp til laga um pungunarrof 2019). Аð pví sögðu pá má ítreka mikilvægi pess að skilgreining hugtaka sé öllum skýr og ljós ef almenningur á að geta tekið upplýsta afstöðu til brýnna pjóðfélagsmála (Chong \& Druckman 2007). Af pessu leiðir að niðurstöðurnar kalla á frekari spurningar og umræðu um hugtakalæsi almennings, sem og hugtakalæsi ákveðinna pjóðfélagshópa.

Almennt má halda pví fram að mismunandi hugtakanotkun í ofangreindum málefnum hafi haft lítil áhrif á viðhorf fólks til málefnanna. Pær niðurstöður koma talsvert á óvart ef litið er til fræðilegrar umfjöllunar um uppruna pekkingar, pólitískrar orðræðu og til markvissra tilrauna stjórnmálamanna til að hafa áhrif á viðhorf fólks með pví að venjubinda hugtök með pessum hætti (Dunmire 2012; Focault [1975]/1979; Merton [1945]/1996; Zerubabel 2018). En pó að niðurstöðurnar sýni ekki endilega meiri stuðning við „,hlutlausari“ hugtökin en pau ,gildishlöðnu“ getur engu að síður hugsast að hlutlausari hugtök mildi afstöðu fólks yfir lengri tíma, pegar hugtökin hafa náð að festast í sessi í almennri orðræðu, hlotið almenna útbreiðslu og eru orðin ráðandi fyrir veruleikann sem pau eiga að lýsa (Chong \& Druckman 2007; Kahneman 2011, 59-61). Árangursrík beiting nýrra hugtaka yfir rótgróin málefni kann pví að hafa áhrif á viðhorf almennings til lengri tíma litið, pó að árangur slíkrar viðmiðabindingar hugtaka sé kannski ekki sýnilegur meðan á umskiptaferlinu stendur, pegar nýja hugtakinu er ætlað að taka við af pví gamla. Pess vegna getur verið að áætlanir heilbrigðisráðherra um að taka upp hugtakið pungunarrof kunni pegar fram líða stundir að verða árangursríkari til að milda enn frekar viðhorf almennings til málefnisins, svo framarlega sem hugtakið festist í sessi og verði ráðandi fyrir málefnið. Áætlanir pingmanna sem settu fram frumvarp um lögleiðingu spilahalla virðast aftur á móti ekki hafa gengið upp, par sem stuðningur við málefnið er lítill og hvorki innleiðing hins nýja hugtaks né lög pess efnis hafa gengið eftir, rúmum fimm árum eftir að frumvarpið var lagt fram. Hugtökin gjald og tollur eru aftur á móti rótgrónari í íslensku máli og prátt fyrir að pau skarist að ákveðnu leyti í almennri orðræðu hafa pau í grunninn ólíka merkingu. Đetta kann að skýra að nokkru leyti marktækan mun á viðhorfum svarenda til peirra spurninga, eftir mismunandi hugtakanotkun, að pessi hugtök eiga sér lengri sögu, en hin sem spurt var um, og jafnframt að merkingu hugtakanna gjald og tollur má að einhverju leyti túlka á mismunandi hátt.

Einnig má leiða að pví líkur að til að ný hugtakanotkun verði venjubundin í orðræðunni purfi málefnið að hafa breiðan stuðning almennings til að byrja með (Chong \& Druckman 2007). Pannig má halda pví fram að tilraun Alpingismannanna sem lögðu fram frumvarp um spilahallir hafi mistekist, eins og sjá má á niðurstöðunum, vegna pess að ekki var í grunninn nægur stuðningur almennings við málefnið. Aftur á móti náðist frumvarp um pungunarrof í gegn, enda er mikill stuðningur almennings við málefnið, sem mun væntanlega marka pá línu að hugtakið pungunarrof mun smátt og smátt taka við af hugtakinu fóstureyðing í almennri umræðu um málefnið pegar fram líða stundir. 
Petta bendir til pess að ákvarðanir stjórnvalda séu ekki teknar í félagslegu tómarúmi. Ef málefnin eru ekki sprottin úr samfélaginu og/eða hafa breiða skírskotun í samfélaginu (eins og á við um spilahallir frekar en um pungunarrof) getur pað reynst valdhöfum erfitt að stýra almenningi af eigin geðpótta með pví að setja slík málefni í fallegan búning til pess að ná breiðari samfélagslegri sátt, og koma sínum málum í gegn með peim hætti (Freedman 2013, 436).

Aftur á móti pá er einnig mikilvægt að setja slíka orðræðugreiningu í víðara samhengi. Фаð kann að vera að sá mismunandi pungi sem settur er í að ramma málefni stjórnmálanna inn í ákveðinn búning og kynna almenningi hafi mismunandi áhrif á almenning. pessu til stuðnings má nefna nýleg dæmi úr hinum engilsaxneska heimi stjórnmálanna; pau gefa til kynna að markvissar herferðir stjórnmálaafla, sem einkennast jafnan af endurtekningu slagorða, auglýsinga og áróðurs, og sem gera jafnvel út á afbökun eða endurskilgreiningu veruleikans, hafi heppnast (Chomsky 2018; Gore 2017; Revelli 2019) - sem staðfestir kannski áhyggjur Orwells. Hins vegar hafa pessar tilraunir íslenskra stjórnmálamanna til að hafa áhrif á viðhorf almennings til málefnanna priggja farið frekar hljótt par sem ekki hefur mátt greina sérstakar herferðir af peirra hálfu til að hafa bein áhrif á viðhorf almennings í pessum efnum. Pví kunna áhrif hugtakanotkunarinnar að vera minni í peim einstöku dæmum sem tekin voru fyrir hér að framan heldur en í stórum herferðum stjórnmálaaflanna. Рað má pví kannski frekar halda pví fram að pólitísk orðræða eins og hér hefur verið greind skapi samræðugrundvöll milli valdhafa og borgara án pess pó að sú orðræða stjórni borgurunum skilyrðislaust (Krauss \& Chiu 1998). Til pess að sátt náist um málefnin purfa pau sem slík að hafa umtalsverðan samfélagslegan hljómgrunn, og virðist pá skipta litlu máli hvaða hugtakanotkun er beitt í orðræðunni heldur fyrst og fremst hvort sátt sé meðal almennings um viðkomandi málefni. Orðræðan kann pó að hafa áhrif á ákveðna hópa fremur en aðra og til lengri tíma fremur en styttri.

Að lokum má nefna helstu takmarkanir rannsóknarinnar. Greiningin hér að framan tekur aðeins fyrir prjú nýleg dæmi um hvernig stjórnmálamenn beita markvisst hlutlausari hugtökum frekar en gildishlöðnum í íslenskum stjórnmálum. Pessi dæmi purfa ekki að endurspegla almenn áhrif hugtakanotkunar stjórnmálamanna hér á landi, eða erlendis, og pví er ekkert hægt að alhæfa um áhrifamátt hugtakanotkunar íslenskara stjórnmálamanna útfrá niðurstöðunum. Fleiri rannsóknir purfa að koma til, sem taka fyrir fleiri dæmi, láta svarendur velja á milli mismunandi hugtaka, sem og skoða áhrif hugtaka á viðhorf almennings yfir lengri tíma (Chong \& Druckman 2007). Einnig kann orðalag spurninganna sem notaðar voru í könnuninni (fyrir utan hugtakanotkunina sem fjallað er um í greininni) að hafa skipt máli. Spurningarnar um spilahallir/spilavíti voru til að mynda ítarlegri en spurningarnar um hin málefnin par sem pær innihéldu frekari lýsingu á starfseminni sem spurt var um, sem kann að hafa aukið sameiginlegan skilning svarenda á viðkomandi málefni (burtséð frá hugtakanotkuninni) og par með dregið úr hugsanlegum mun á svörum við spurningunum á grundvelli mismunandi hugtakanotkunar. Að lokum má geta pess að pó að áhugaverðar vísbendingar hafi komið fram í gögnunum, til að mynda varðandi mun á afstöðu ýmissa hópa til málefnanna priggja, 
reyndust sum tölfræðileg sambönd í pá áttina ekki alltaf marktæk. Đað kann að hafa haft áhrif á tölfræðilega marktekt að úrtakinu var í byrjun skipt í tvennt og pegar gögnin eru greind enn frekar, eftir ýmsum bakgrunnsbreytum, pá hefur helmingsskerðing á fjölda svara áhrif á marktektarútreikninga og gerir kröfu um enn sterkari sambönd milli breyta heldur en í stærri úrtökum. bað gæti pví verið mikilvægt í rannsóknum pegar skipta á úrtaki í tvennt eins og gert var hér að byggja á stærra grunnúrtaki í peim tilgangi að auka áreiðanleika og styrkja niðurstöður ítarlegri greiningar.

\section{Aftanmálsgreinar}

1 Íslensk pýðing höfundar.

2 Íslensk pýðing, Rafn Kjartansson.

3 Íslensk pýðing, Rafn Kjartansson.

4 Könnunin náði alls til 1954 meðlima í netpanel Félagsvísindastofnunar HÍ. Netpanell Félagsvísindastofnunar samanstendur af fólki 18 ára og eldra á landinu öllu sem hefur sampykkt að taka pátt 1 netkönnunum á vegum stofnunarinnar. Netpanellinn byggist á tilviljunarúrtaki úr pjóðskrá. Söfnun í netpanel á sér stað jafnt og pétt og fylgst er vel með samsetningu hans. Meðal annars er pess gætt að dreifing kyns, aldurs, búsetu, menntunar og tekna sé sem líkust pví sem hún er meðal allra landsmanna, 18 ára og eldri. Með pví að tryggja gæði netpanelsins með framangreindum hætti er möguleiki á að alhæfa um niðurstöður rannsókna sem byggjast á svörum úr honum og voru gögnin vigtuð eftir kyni, aldri, búsetu og menntun til pess að niðurstöður gæfu sem réttasta mynd af pýði. Allar pýðistölur eru fengnar af vef Hagstofunnar.

5 Úrtökin fyrir hverja og eina spurningu voru tekin með tilviljunarkenndum hætti. Đ.e. pað var háð tilviljun hvort svarandi fékk spurningu um spilahallir eða spilavíti, og svo koll af kolli. Marktektarpróf sem gerð voru á hópunum í hverjum spurningaflokki sýndu að hóparnir sem svöruðu mismunandi spurningum voru allir sambærilegir og endurspegla pannig upprunalega úrtakið.

\section{Heimildaskrá}

Adams, P.J. (2007). Gambling, Freedom and Democracy. London: Routledge.

Becker, H.S. (2007). Telling About Society. Chicago: Chicago University Press.

Berger, P. og Luckmann, T. ([1967]/1991). The Social Construction of Reality: A Treatise in the Sociology of Knowledge. London: Penguin.

Bloom, A.H. (1981). The Linguistic Shaping of Thought: A Study in the Impact of Language on Thinking in China and the West. Hillsdale, NJ: Erlbaum.

Bourdieu, P. ([1983]/1991). Language and Symbolic Power. Cambridge: Harvard University Press.

Chomsky, A. (2018). "They Take Our Jobs!" And 20 Other Myths about Immigration. Boston: Beacon Press.

Chong, D. og Druckman, J.N. (2007). „Framing Theory“, Annual Review of Political Science 10, 103-126.

Durkheim, E. ([1915]/1965). The Elementary Forms of the Religious Life. New York: Free Press.

Durkheim, E. ([1938]/1962). The Rules of the Sociological Method. Chicago: The Free Press of Glencoe.

Dunmire, P.L. (2012). „Political Discourse Analysis: Exploring the Language of Politics and the Politics of Language", Language and Linguistics Compass 6(11), 735-751.

Edelman, M. (1988). Constructing the Political Spectacle. Chicago: Chicago University Press.

Fairhurst, G.T. (2011). The Power of Framing: Creating the Language of Leadership. San Francisco: Jossey-Bass. Foucault, M. ([1969]/1982). The Archaeology of Knowledge: And the Discourse on Language. New York: Vintage Books.

Foucault, M. (1973). The Order of Things: An Archaeology of the Human Sciences. New York: Vintage Books. Foucault, M. ([1975]/1979). Discipline and Punish: The Birth of the Prison. New York: Vintage Books.

Freedman, L. (2013). Strategy: A History. Oxford: Oxford University Press. 


\section{STJÓRNSÝSLA}

Frumvarp til laga um spilahallir (2015). Dingskjal 156 - 153. Mál., 144. Löggjafarping 2014-2015. Sótt af https://www.althingi.is/altext/144/s/0156.html

Frumvarp til laga um pungunarrof (2019). Bingskjal 521 - 393. Mál. Stjórnarfrumvarp, 149. Löggjafarping 2018-2019. Sótt af https://www.althingi.is/altext/pdf/149/s/0521.pdf

Galbraith, J.K. (1962). The Affluent Society. London: Pelican.

Goffman, E. (1974). Frame Analysis: An Essay on the Organization of Experience. Boston: Northeastern University Press.

Gore, A. (2017). The Assault on Reason: Our Information Ecosystem, from Age of Print to the Age of Trump. New York: Penguin.

Herman, E.S. og Chomsky, N. (1988). Manufacturing Consent: The Political Economy of the Mass Media. New York: Pantheon.

Hoffman, C., Lau, I.Y. og Johnson, D.R. (1986). „The Linguistic Relativity of Person Cognition: An English-Chinese Comparison", Journal of Personality and Social Psychology 51(6), 1097-1105.

Íslensk nútímamálsorðabók (2020a). Spilaviti. Sótt 12. ágúst af https://islenskordabok.arnastofnun.is/ ord $/ 38685$

Íslensk nútímamálsorðabók (2020b). Tollur. Sótt 12. ágúst af https://islenskordabok.arnastofnun.is/ ord $/ 42039$

Kahneman, D. (2011). Thinking Fast and Slow. London: Penguin.

Khoo, J. (2017). „Code Words in Political Discourse“, Pbilosophical Topics 45(2), 33-64.

Krauss, R.M og Chiu, C.Y. (1998). „Language and Social Behavior“, í D.T. Gilbert, S.T. Fiske og G. Lindzey (ritstj.), The Handbook of Social Psychology (bls. 41-88). New York: McGraw-Hill.

Landlæknir (2020). Fóstureyðingareydublad. Sótt 12. ágúst af https://www.landlaeknir.is/servlet/file/ store93/item2211/Fóstureyðingareyðublað\%202006.pdf

Lessig, L. (1995). „The Regulation of Social Meaning“, The University of Chicago Law Review 62(3), 9431045.

Mead, G.H. (1972). Mind, Self \& Society: From a Standpoint of a Social Behaviorist. Chicago: Chicago University Press.

Merton, R.K. ([1945]/1996). On Social Structure and Science. Chicago: Chicago University Press.

Orwell, G. ([1949]/2017). Nineteen Eighty-four. London: Penguin.

Perinbanayagam, R. (2018). The Rhetoric of Signs. Bloomington, IN: Archway Publishing.

Polanyi, M. ([1958]/1998). Personal Knowledge: Towards a Post Critical Philosophy. London: Routledge.

Polanyi, M. ([1959]/2014). The Study of Man. Eastford, CT: Martino Fine Books.

Revelli, M. (2019). The New Populism: Democracy Stares into the Abyss. London: Verso.

Stjórnarráð Íslands (2019). Vegaframkvamdir - leiðir til fjármögnunar. Samgöngu- og sveitastjórnarráðuneytið. Sótt af https://www.stjornarradid.is/library/02-Rit--skyrslur-og-skrar/SRN_Skýrsla_Fjármögnun $\% 20$ samgöngukerfisins.pdf

Svavar Sigmundsson (ritstj.) (2012). Íslensk sambeitaorðabók. Reykjavík: Forlagið.

van Dijk, T.A. (2002). „Political Discourse and Political Cognition“, í P. Chilton og C. Shaffner (ritstj.), Politics as Text and Talk: Analytic Approaches to Political Discourse (bls. 203-237). Amsterdam: John Benjamins Publishing Company.

Vigotsky, L.S. (1962). Thought and Language. New York: Wiley.

White, I.K. (2007). ,When Race Matters and When it Doesn't: Racial Group Difference in Response to Racial Clues", American Political Science Review 101(2), 339-54.

Wittgenstein, L. ([1921]/2001). Tractatus Logico-Philosopbicus. London: Routledge.

Zembylas, M. (2010). „Critical Discourse Analysis of Multiculturalism and Intercultural Education Policies in the Republic of Cyprus“, The Cyprus Review 22(1), 39-59.

Zerubavel, E. (2018). Taken for Granted: The Remarkable Power of the Unremarkable. Princeton: Princeton University Press.

Zetter, L. (2014). Lobbying: The Art of Political Persuasion. Hampshire: Harriman House. 


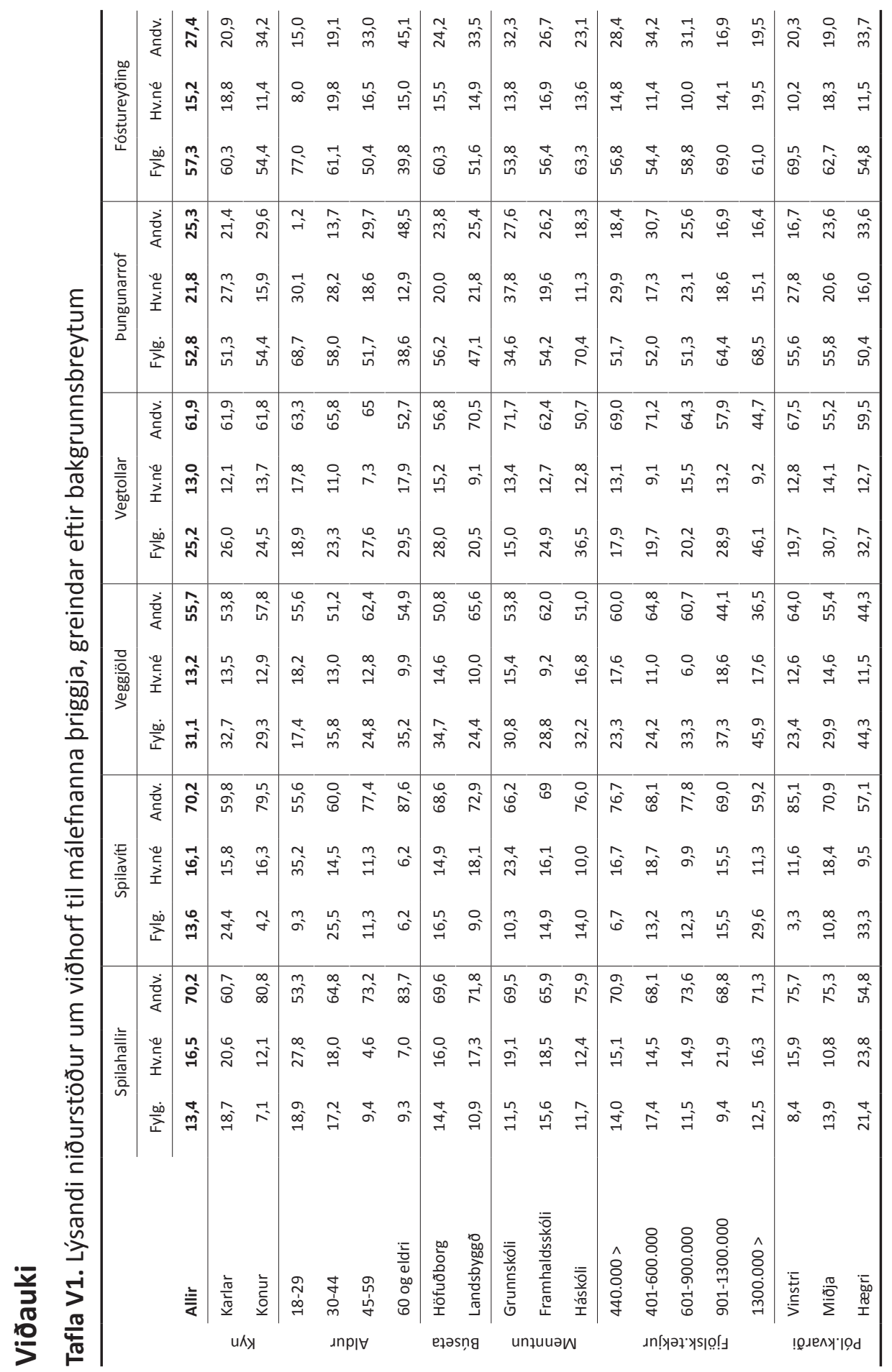

